\title{
Conceptual approach to depreciation potential
}

\author{
Mariya Shchukina ${ }^{1 *}$ \\ ${ }^{1}$ Perm National Research Polytechnic University, Department of Economics and Finance, 614000, Komsomolsky avenue 29, Perm, \\ Russia
}

\begin{abstract}
The paper considers the category of "economic potential", reveals the approaches of researchers to the understanding of economic potential. Investment potential is one of the components of economic potential. The presented indicators (factors) reflecting the investment potential do not reflect the sources of investment in fixed assets. In this regard, the author proposes to introduce the concept of "depreciation potential". The content of the depreciation potential is clarified. The need for the importance of the use of depreciation charges as a source of funding is substantiated. The author proposes to single out the real and nominal depreciation fund, the ratio of which allows calculating the coefficient (index) of the use of the depreciation fund, which is one of the indicators to assess the depreciation potential. The proposed coefficient is calculated on the basis of statistical data from the Perm Territory. The obtained values indicate the intended use of the depreciation fund of enterprises of the Perm Territory.
\end{abstract}

\section{Introduction}

The risks of economic activity, crisis phenomena and unfavorable epidemiological situation negatively affects the functioning of any socio-economic system: an enterprise, a region, a country. One of the ways to improve the efficiency of the system at various levels is the mobilization of internal reserves and the rational use of available resources. Competent depreciation policy, contributing to the intended use of depreciation deductions, is one of the mechanisms leading to the increase in the competitiveness of an economic entity by increasing the technical level of the applied fixed assets.

When investment financing in fixed assets, economic entities use both their own funds and borrowed funds. Net profit and depreciation charges are considered as own sources of financing. Loans from banking sector and other organizations, financial resources from the budget, foreign investments, funds of state extra-budgetary funds are considered as attracted funds.

Mazurina T.Yu. notes that in the period from 2000 to 2009 there was a tendency to the increase in the share of borrowed funds, which reflected the instability of financial situation [1]. However, as statistics show, over the past decade, the opposite situation has been observed. Today there is an increase in the proportion which is attributed to own sources when financing fixed assets. Table 1 reflects the structure of sources of financing investments in fixed assets [2,3].

According to the data in the table, it can be seen that there is a steady trend towards the increase in the share of own funds over the studied period. Average share in the period from 2008 to 2013 is $41 \%$, and in the period from 2014 to $2019-51 \%$. A $10 \%$ reduction in the average share of borrowed funds indicates the increase in the financial stability of organizations.

Table 1. Structure of sources for investment financing in fixed assets

\begin{tabular}{|l|c|c|c|c|c|c|c|c|c|c|c|c|}
\hline Source share, \% & 2008 & 2009 & 2010 & 2011 & 2012 & 2013 & 2014 & 2015 & 2016 & 2017 & 2018 & 2019 \\
\hline Own & 39,5 & 37,1 & 41 & 41,9 & 44,5 & 45,2 & 45,7 & 50,2 & 51 & 51,3 & 53,1 & 55,1 \\
\hline Attracted & 60,5 & 62,9 & 59 & 58,1 & 55,5 & 54,8 & 54,3 & 49,8 & 49 & 48,7 & 46,9 & 44,9 \\
\hline
\end{tabular}

Table 2. Share of unprofitable organizations from the total number

\begin{tabular}{|l|c|c|c|c|c|c|c|c|c|c|c|c|}
\hline \multicolumn{1}{|c|}{ Item } & 2008 & 2009 & 2010 & 2011 & 2012 & 2013 & 2014 & 2015 & 2016 & 2017 & 2018 & 2019 \\
\hline $\begin{array}{l}\text { Share of } \\
\text { unprofitable } \\
\text { organizations } \\
\text { from the total } \\
\text { number,\% }\end{array}$ & 28 & 32 & 29,9 & 30 & 29,1 & 31 & 33 & 32,6 & 29,5 & 31,9 & 33,1 & 32,5 \\
\hline
\end{tabular}

\footnotetext{
* Corresponding author: mvkrasn@ mail.ru
} 
However, there is the increase in the share of unprofitable enterprises. The presence of a high share of unprofitable organizations from the total number of enterprises and its insignificant growth over the past three years (up to $32 \%$ on average) indicates that the investment opportunities of organizations are limited by depreciation deductions.

The statistics presented in Table 2 indicate the importance of the use of depreciation deductions as a source of financing [3].

The only own source of loss-making enterprises to finance investments in fixed assets is depreciation charges, which makes the problem of the intended use of depreciation charges actual. Depreciation charges form a depreciation fund that should be used for simple or extended reproduction of fixed assets. The level of investment in fixed assets determines the potential of an economic entity.

\section{Materials and methods}

The following types of potential are described in literature: "economic", "financial", "investment", "property", "innovative", "socio-economic", "digital", "network", "personnel", "market" and "industrial". Economic potential is a fairly broad concept. There are many studies devoted to the assessment of economic potential, including methods for the assessment of potential. Over the past year, the greatest interest of researchers studying the economic potential has been provoked by the issues of measuring and modeling the economic potential of a region, city [4-6], the economic potential of individual enterprises and industries [7-8] and the development of the economic potential of municipal units [9].

Economic potential integrates several private potentials that are functional. Researchers determine the structure of economic potential in different ways, highlighting many components that form economic potential. For example, Bakhtin M.N., Petrykina I.N., Pleshakov S.S. distinguish the following partial components of economic potential: demographic, natural resource, financial, labor, production, consumer, infrastructural and institutional. Table 3 presents the systematization of existing opinions about private potentials included in economic potential.

According to Table 3, we can see that there is no single approach to the allocation of private potentials. In addition, if we consider the category of «socioeconomic potential », for example, A.Yu. Vavilova, A.V. Letchikov, M.A. Sokolova identify a larger list of components of socio-economic potential: production, budget, financial, investment, labor, energy, agricultural, consumer, foreign trade and others [10]. The private potential associated with investment activities is investment potential. The study of the literature related to investment potential allows stating that there are different interpretations of this term. There is no single methodology to calculate indicators that determine the investment potential.
Table 3. Approaches to structuring economic potential into private (functional) potentials

\begin{tabular}{|l|l|}
\hline $\begin{array}{c}\text { Authors (author) } \\
\text { of the approach }\end{array}$ & \multicolumn{1}{|c|}{$\begin{array}{c}\text { List of private (functional) } \\
\text { potentials }\end{array}$} \\
\hline Kharina V.S. & $\begin{array}{l}\text { natural resource, investment, } \\
\text { labor, financial, innovative }\end{array}$ \\
\hline Mukhina E.G. & $\begin{array}{l}\text { industrial natural, geopolitical, } \\
\text { demographic (labor), potential of } \\
\text { the social sphere }\end{array}$ \\
\hline $\begin{array}{l}\text { Bakhtin M.N., } \\
\text { Petrykina I.N., } \\
\text { Pleshakov S.S. }\end{array}$ & $\begin{array}{l}\text { demographic, natural resource, } \\
\text { financial, labor, production, } \\
\text { consumer, infrastructural, } \\
\text { institutional }\end{array}$ \\
\hline Kovalev V.V. & property, financial \\
\hline $\begin{array}{l}\text { Krivoruchko O. } \\
\text { N. }\end{array}$ & $\begin{array}{l}\text { labor, investment, natural } \\
\text { resource, innovative }\end{array}$ \\
\hline Gunina I.A. & $\begin{array}{l}\text { personnel (labor), financial, } \\
\text { production, innovative, } \\
\text { informational }\end{array}$ \\
\hline $\begin{array}{l}\text { Efendieva A.A., } \\
\text { Temrokova A.Kh. }\end{array}$ & $\begin{array}{l}\text { investment, financial, } \\
\text { organizational, innovative }\end{array}$ \\
\hline
\end{tabular}

According to Vavilova A.Yu., Letchikov A.V., Sokolova M.A., the investment potential is measured by such indicators as investments in fixed assets, investments in fixed assets with the participation of foreign capital and the volume of investments from foreign investors [10]. All of these indicators are calculated per capita. Grishina I.V., Polynev A.O. proposed a method to assess the socio-economic situation of the regions of the Russian Federation, considering 16 indicators grouped into four blocks [11]. The investment and financial block includes such indicators as the balanced financial result per employee, the amount of investment in fixed assets, the share of profitable enterprises and organizations and the amount of payable accounts.

We see that both «economic potential» and «socioeconomic potential» include investment potential, but there is a substitution of investment potential for investment and financial one. The existing methods for the assessment of the indicators of investment potential are not related to sources of financing for investment activities and do not reveal the sources of investment in fixed assets. In a number of existing interpretations of the concept of «investment potential» we are talking about the resources of an individual economic entity, which are directed to investment needs in order to ensure economic growth and increase efficiency. However, the source of these resources is not revealed: whether they used their own or borrowed sources.

\section{Results and discussion}

It is proposed to introduce the concept of «depreciation potential ». Under the depreciation potential we mean the ability of an economic entity to create the increase in the value of fixed assets at the expense of its own internal source - the depreciation fund. Figure 1 shows the relationship between economic, investment and depreciation potential. 
The depreciation potential is considered as a private (functional) potential in relation to the investment potential, which is a component of economic potential. The depreciation potential can be considered in the context of three levels: enterprise, region and country. Depreciation potential includes two components: resources and directions of their use. Let us consider the process of formation of resources, formed from the depreciation fund and their directions of use.

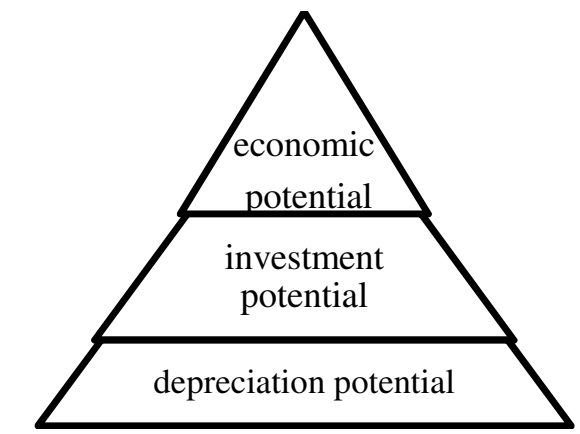

Figure 1. Relationship of economic, investment and depreciation potential

Depreciation charges as a result of the depreciation process are accumulated in the depreciation fund. Nowadays there is no interpretation of the concept of «depreciation fund» in the regulatory literature. According to R.G. Sabiryanova and Z.M. Bikmetova, the depreciation fund is a fund of funds, which is intended for the refund and renewal of fixed assets [12]. A.P. Grigoriev determines the depreciation fund as funds from depreciation that can be used to repair fixed assets [13]. Researchers highlight the use of the depreciation fund for the renewal of fixed assets. The nominal and real depreciation fund should be identified.

The accumulated depreciation for a particular period determines the maximum amount of accumulated funds that form the nominal depreciation fund of an enterprise. The accumulated depreciation forms the resources of the depreciation potential. Real depreciation fund will be considered as the amount of funds actually allocated for the purchase of new fixed assets. Modernization, renovation, repair, reconstruction, technical re-equipment, new construction and robotization are the directions of the use of the resources of depreciation potential. Table 4 shows the resources and directions of the use of the resources of amortization potential.

Table 4. Depreciation potential components

\begin{tabular}{|c|c|}
\hline resources & directions of resource use \\
\hline \multirow{5}{*}{$\begin{array}{ll}\text { amount } & \text { of } \\
\text { accumulated } & \\
\text { depreciation } & \end{array}$} & - new fixed assets; \\
\hline & $\begin{array}{l}\text { - } \quad \text { modernization } \\
\text { renewal of fixed assets; }\end{array}$ \\
\hline & $\begin{array}{l}\text { - } \\
\text { technical re-equipment; }\end{array}$ \\
\hline & - robotization; \\
\hline & - new construction \\
\hline
\end{tabular}

The index (coefficient) of the use of the amortization fund can be used as one of the indicators for the assessment of depreciation potential, which allows assessing its level of use. This index will act as a sub-index in relation to investment potential. The index (coefficient) of the use of the depreciation fund is determined by Formula 1.

$$
K_{\text {useDf }}=\frac{D f_{\text {real }}}{D f_{\text {nominal }}}(1)
$$

Where $D f_{\text {real }}$ - real depreciation fund, $D f_{\text {nominal }}-$ nominal depreciation fund.

In order to calculate the proposed index of the use of depreciation fund for an enterprise, it is necessary to collect information on the size of the nominal and real depreciation fund on the basis of financial statements and accounting data. To calculate the proposed index of the use of the depreciation fund for a region, it is necessary to use statistical data containing information on the accumulated depreciation charges and the amount of investments in real assets. According to the proposed formula in Table 5, this index was calculated on the basis of the statistical data of the Perm Territory.

According to the table, we see that the values of the utilization rate of depreciation fund have values exceeding one. This means that the entire amount of accumulated depreciation charges was invested in fixed assets. At the same time, the real amount of investments in 2013 and 2014 was twice higher than the nominal depreciation fund, which allows concluding that net profit is used as a source of investment or attracted funds. However, we note that there is a clear tendency to "approach" to one.

As an example, indices were calculated for several enterprises of the chemical industry of the Perm Territory, the results are shown in Table 6. KamteksKhimprom enterprise has significant fluctuations in the index during the studied period; the average value of the index is 1.1. This is a signal that for the entire studied period the created depreciation fund was used for its intended purpose.

The indices of Sorbent enterprise also have significant fluctuations: from 0.42 to 4.17 for the calculation period. Only in 2016 and 2017 the depreciation fund was not fully capitalized into fixed assets, while values exceeding one in subsequent years show that the unused balance of depreciation charges was directed to renewal, reconstruction, modernization and the acquisition of new fixed assets. The indices of Solikamsk Magnesium Plant allow revealing that in periods when the values did not exceed one, their level was quite high - 70 and $86 \%$ (in the corresponding years), which indicated $30 \%$ and $15 \%$ of unused resources of depreciation potential.

A constant excess of the index of one is not a prerequisite, since in this case the funds of the founders are diverted from the turnover or there is a financial and operational need to cover the difference between real investments and the created amortization fund.

If the index value approaches one within 5-7 years, this indicates the effectiveness of the developed depreciation policy of the enterprise and the intended 
use of depreciation funds, while one-time deviations of the coefficient are possible when the values are low (0.2-0.6). If the funds are not used in full according to their intended purpose in the current period, then they are accumulated (accumulated depreciation fund) and can be capitalized into fixed assets in the next period.

Table 5. Calculation of the index (coefficient) of the use of depreciation fund based on the statistical data of the Perm Territory

\begin{tabular}{|l|c|c|c|c|c|c|}
\hline \multicolumn{1}{|c|}{ Indicator } & 2013 & 2014 & 2015 & 2016 & 2017 & 2018 \\
\hline $\begin{array}{l}\text { Accumulated } \\
\text { depreciation, mln. rub. }\end{array}$ & 83498.77 & 84947.04 & 102909.42 & 118151.38 & 130974.58 & 127645.45 \\
\hline $\begin{array}{l}\text { Fixed capital } \\
\text { investments, mln. rub. }\end{array}$ & 183030.30 & 171289.30 & 186384.60 & 189301.50 & 188233.30 & 184148.80 \\
\hline $\begin{array}{l}\text { The use of depreciation } \\
\text { fund }\end{array}$ & 2.19 & 2.02 & 1.81 & 1.60 & 1.44 & 1.44 \\
\hline
\end{tabular}

Table 6. Indices (ratios) of the use of depreciation fund based on the data of the accounting (financial) statements of chemical

\begin{tabular}{|l|c|c|c|c|c|c|c|}
\hline \multicolumn{1}{|c|}{ Enterprise } & 2014 & 2015 & 2016 & 2017 & 2018 & 2019 & 2020 \\
\hline Kamteks-Khimprom & 1.75 & 1.41 & 0.24 & 0.61 & 0.86 & 1.97 & 0.83 \\
\hline Sorbent & 1.53 & 1.37 & 0.42 & 0.56 & 1.35 & 2.09 & 4.17 \\
\hline Solikamsk Magnesium Plant & 1.02 & 0.86 & 1.83 & 0.70 & 1.64 & 1.13 & 1.22 \\
\hline
\end{tabular}

However, in practice, the assets of the depreciation fund are not always used for their intended purpose. Firstly, this is explained by the lack of resources at enterprises to finance current activities and cash gaps. Secondly, the presence of inflation stimulates the preterm use of the depreciation fund for other purposes. Thirdly, it is connected with the risks associated with the storage of free funds and low deposit rates. In this case, the depreciation fund has a passive mechanism of action, since the funds are used for other purposes.

The calculation of the average index for the studied period will show how much the assets of depreciation fund were used for their intended purpose as a whole for the period, taking into account the redistribution of monetary resources over time.

\section{Conclusion}

The calculation of the index (coefficient) of the use of depreciation fund allows economic entities to understand where depreciation deductions are used. Since the use of depreciation funds is not reflected in accounting, the use of the proposed coefficient allows determining the degree of intended use of depreciation fund. Low values of the index of the use of depreciation fund indicate a weak depreciation potential of the subject (region, enterprise).

The practical relevance of this study is in the possibility to compare regions on the basis of the proposed index, identifying regions with a high depreciation potential. The calculation of the proposed coefficient at the enterprise level allows evaluating the effectiveness of depreciation policy, comparing enterprises on the basis of their depreciation potential in alternative investments.

\section{References}

1. T.Yu. Mazurina, Finance and Credit. 11, 14-23, (2012).

2. Investments in Russia Retrieved from: https://rosstat.gov.ru/folder/210/document/1323 8

3. Finance of Russia Retrieved from: https://rosstat.gov.ru/folder/210/document/1323 7

4. N.A. Burakov, A. Ya. Rubinstein Spatial Economics. 16 (1), 20-50, (2020) DOI: 10.14530 / se.2020.1.024-050

5. I.M. Drapkin, E.O. Dubinina Economy of the region, 16 (1), 310-324, (2020). https://doi.org/10.17059/2020-1-23

6. E.G. Shcherban Bulletin of the SSEU. 2 (81), 67-71, (2020)

7. L. D. Efanova, V. L. Polyakova Bulletin of the University, 5 , 141-144 (2019) DOI: 10.26425 / 1816-4277-2019-5-141-144

8. A.I. Golubeva, V.I. Dorokhova, A.V. Konovalov, Yu.V. Shumatbaeva, K.V. Pavlov Bulletin of the Agroindustrial Complex of the Upper Volga Region. 1 (49), 59-67, (2020) DOI: 10.35694 / YARCX.2020.49.1.013

9. V.S. Antonyuk, A.V. Rezepin, D.V. Kremer Bulletin of SUSU. Series "Economics and Management", 14(2), 18-27, (2020). DOI: 10.14529 / em200202

10. A.Yu. Vavilova, M.A. Letchikov, M.A. Sokolova, Bulletin of the Udmurt University. 2, 31-43, (2006)

11. I.V. Grishina, A.O. Polynev Modern productive force,. 34-48, (2012)

12. R.G. Sabiryanova, Z.M. Bikmetova Problems of modern economics. 2, 403-406, (2014)

13. A.P. Grigoriev Economic analysis: theory and practice. 17(8), 1584 - 1600, (2018) doi.org/10.24891/ea.17.8.1584 